\title{
Why is terrorism a man's business?
}

\author{
Anne Maria Möller-Leimkühler*
}

\author{
Department of Psychiatry and Psychotherapy, Ludwig-Maximilians-University of Munich, Munich, Germany
}

Terrorism, whether it is group-related or performed as lone actor terrorism, is a predominantly male phenomenon. Generally and throughout history, young males have been the main protagonists of criminal and political violence.

This article aims to contribute, from different perspecives, to the question of what makes young men violent. These include neurobiological aspects, such as sex differences in the brain that predispose males to physical aggression and violence; gender role aspects, with regard to aggression and violence being basic components for demonstrating and reconstructing masculinity; demographic aspects of male youth bulges as potential breeding grounds for terrorism; aspects of group dynamics and identity fusion in the process of radicalization; and psychosocial characteristics of lone actor terrorists, which differ from group-related terrorists.

It is concluded that in addition to ideological, political, economic, regional, demographic, or psychosocial causes, experiences of threatened masculinity may be an underlying factor and driving force for terrorism.

Received 21 March 2017; Accepted 30 May 2017; First published online 2 August 2017

Key words: Group, identity fusion, masculinity, men, terrorism, youth bulge.

\section{Terrorism—Some Principal Aspects}

Terrorism is a highly contested concept. It includes numerous different national, academic, and political definitions; however, for decades a legal definition was missing. A first consensus has recently been achieved by the General Assembly of the United Nations:

Terrorism refers, on the one hand, to a doctrine about the presumed effectiveness of a special form or tactic of fear-generating, coercive political violence and, on the other hand, to a conspirational practice of calculated, demonstrative, direct violent action without legal or moral restraints, targeting mainly civilians and non-combatants, performed for its propagandistic and psychological effects on various audiences and conflict parties. ${ }^{1}$

The doctrine may be based on fundamentalist political or religious ideologies that legitimize all kinds of violence. For example, Islamic extremism names all non-Muslims and even liberal Muslims as infidels, who must be killed until there is no other religion left but the "true faith."

Terrorism as coercive political violence may be employed by illegal state repression or by nonstate actors;

\footnotetext{
* Address for correspondence: Prof. Dr.rer.soc Anne Maria MöllerLeimkühler, Department of Psychiatry and Psychotherapy, Ludwig-MaximiliansUniversity of Munich, Nussbaumstr. 7, D-80336 Munich, Germany.

(Email: anne-maria.moeller-leimkuehler@med.uni-muenchen.de)
}

the latter may act in small groups or diffuse transnational networks, but increasingly also as single actors ("lone-wolf" terrorism). This has been described as the changing face of terrorism in the 21 st century. ${ }^{2}$ Lone-wolf attackers are meanwhile the main perpetrators of terrorist activity in Western societies, mainly in the US, but recently also in France and Germany, causing $70 \%$ of all deaths caused by terrorists over the past 10 years. Half of all attacks worldwide with a connection to the so-called Islamic State (also known as ISIS or ISIL) have been conducted by lone actors. ${ }^{3}$ However, Islamic fundamentalism is not the main driver of terrorism in Western countries; lone-wolf terrorists also have been inspired by political extremism, nationalism, and racial and religious supremacy (eg, the case of far-right terrorist Anders Behring Breivik, who committed the 2011 Norway attacks and killed 77 persons).

The direct victims of terror attacks are not the ultimate target but serve as message generators: the attack is documented by online social media platforms and mass media, which further reinforces the terrorists' focus on public attention, public fear, and intimidation, as well as effects of propaganda for their message and recruitment of potential terrorists. For instance, online publishing of filmed beheadings by Al Qaeda have been intended to serve as a display of power and enactment. Similarly, the World Trade Center assault in New York on September 11, 2001, can be considered as a perverse performance of omnipotence and the power to cause 
chaos, confusion, and fear, not primarily to legitimize a political ideology. ${ }^{4}$

Terrorism is a highly complex phenomenon shaped by political and socio-economic conditions, as well as by ethnic and ideological conflicts and their history, demographic characteristics, regional segregation, and access to weapons.

There are 2 distinct sets of factors associated with terrorism depending on the developmental status of the country. Between 1989 and 2014, 93\% of all terrorist attacks occurred in countries with high levels of state-sponsored terror. ${ }^{3}$ Depending on the level of development, factors such as youth unemployment, militarization, levels of criminality, or distrust in the electoral process can be statistically identified as correlates of terrorism in Organisation for Economic Co-operation and Development (OECD)-affiliated countries. In developing countries, factors such as the history of conflict, levels of corruption, acceptance of the human rights, and group-based inequalities are more significantly related to terrorist activity. ${ }^{3}$ As measured by the Global Terrorism Index, countries with the highest rate of terrorism are Iraq, Afghanistan, Nigeria, Pakistan, and Syria. The most active and global terror groups are ISIL (Islamic State of Iraq and the Levant), Boko Haram, the Taliban, and Al Qaeda.

Especially since 2014, increased Islamic terrorist activity in Europe can be observed. This increase can be related to spill-over effects of the Syrian Civil War, to the so-called "Iraq effect" caused by the US war under President Bush against Iraq, ${ }^{5}$ and to the European continuing migrant crisis, which facilitates the infiltration of terrorists. As one consequence of the upsurge of ISIS/ISIL and of millions of incoming refugees, there is a rise not only of anti-Muslim attitudes in Europe, ${ }^{6}$ but also an increase of antiimmigration and Islamophobic violence as well as militant, right-wing extremist groups. The upsurge of ISIL is further due to the fact that it has successfully begun to use Europe as a new recruitment base for potential terrorists, even though it has lost ground in the Middle East.

In fact, from 2012 to 2015 , more than 400 people left Belgium for ISIL-controlled Iraq and Syria, and nearly 1,200 left France to join jihad terrorism. ${ }^{7}$ The European Police Agency Europol estimates that more than 5,000 Europeans have left to join Islamist fighters in Syria, and the problem for security services is aggravated when these people return with training and a mission. ${ }^{8}$ In Germany, for example, 550 potentially violent attackers have been identified.

When estimating the current terrorist threat in Western societies, Renard ${ }^{8}$ states "that it is very serious, even increasing, but not existential" (p. 7). Statistically, people would have a higher chance of dying from a car accident, or falling off their bed or a ladder than dying from terrorism.

\section{Terrorism Is a Man's Business}

As is obvious from the introduction, violence is a multicausal behavior and has been subject to various disciplines with a variety of somewhat controversial theories. However, a fact more than apparent is that physical violence, whether it is individual or collective, such as wars, armed conflicts, genocides, or terrorism, is a predominantly male phenomenon. Generally and throughout history, young males have been the main protagonists of criminal as well as political violence. However, gender is widely ignored in terrorism and violence research. Where it is addressed, it refers mainly to women, not to men, because the latter are held to be the "norm" of violent behavior, so self-evident that further explanation is not needed. This article focuses on violent young males from different perspectives. What makes men violent? A comprehensive approach to better understand this phenomenon includes neurobiological, psychological, and social factors that increase the risk of violence under certain societal conditions. These factors will also contribute to the question of why especially young males become radicalized and why they are prone to violent extremist groups.

\section{Neurobiological Predispositions for Male Violence}

Gender is an issue of nature and nurture. Maleness, respectively, masculinity is not solely a sociocultural construct, as many social scientists still believe, but is also shaped by sex differences in brain structure and function, stress response, and genetics. That does not mean that males are "hardwired" for violence, but it does mean that they may be more disposed to aggression and violence than females. ${ }^{9,10}$ Numerous examples of sex differences in the brain, in brain regions and circuits, have been documented that are relevant regarding violent behavior. In addition, a mutation of monoamine oxidase A (MAOA), a gene encoding enzyme responsible for the breakdown of the neurotransmitters norepinephrine, serotonin, and dopamine, has been proven that makes affected males more disposed to antisocial and violent behavior, especially when they had experienced maltreatment or neglect in their childhood. ${ }^{9,11}$ With regard to brain structure, the volume of the male amygdala (center of emotion processing) is larger compared to that of females, whereas the orbitofrontal cortex, which controls negative emotions emerging from the amygdala, is smaller. As brain researchers conclude, males may be less able to regulate negative emotions and so may be more prone to impulsive behavior. ${ }^{12}$ With respect to neurotransmitters, data indicate that low levels of serotonin may reinforce aggressiveness, impulsivity, and risk-taking behavior in males, especially in stressful situations. ${ }^{13-15}$ While women under stress may 
be protected by estrogen and oxytocin, and may respond with prosocial strategies such as communication and help-seeking, men tend to respond with a higher release of cortisol and testosterone, which is associated with the fight or flight response, particularly when they feel threatened in their social status. ${ }^{16}$ Unlike in animal studies, testosterone in human males may not be directly associated with physical aggression, but rather with social dominance. Males with high testosterone, when viewing angry faces, display less activation of the amygdala than those with low testosterone, which indicates that they feel less threatened by the anger of others. ${ }^{17}$ Furthermore, an association with delinquent and violent behavior has been found in late adolescent males. ${ }^{12}$ Specifically in their early adolescence, males are experiencing an excessive rise of testosterone, driving them to aggressive, risk-taking behavior and sensationseeking, which is significantly reinforced by peers. ${ }^{18}$ Risky behavior in adolescents seems also to be triggered by a specific heightened sensitivity of the dopaminergic reward system ("no risk, no fun"). However, risky behavior does not guarantee rewards, but may as well have negative outcomes, the worst of which is increased mortality due to suicides, traffic accidents, unintentional self-injuries, and violence. ${ }^{19}$ This is partly due to an imbalance of brain maturing in adolescent males, with the orbitofrontal cortex maturing later and more slowly (about 2 years later compared to females), while the amygdala/the limbic regions develop earlier and more quickly, probably impacting rational or moral decision making. $^{20}$

With highly professional media marketing strategies, explicitly focusing on heroism and adventure (similar to Hollywood scripts ${ }^{21,22}$ ), ISIL is targeting mainly adolescent males, whose identity is typically fragile and malleable in their teenage years. Longing for purpose and adventure, young males may be particularly susceptible to ISIL's promises (money, guns, and girls). In addition, throughout history rebellion against the establishment (family, school, state, church) has always been a strong motivator in young males.

Recently it has been reported that even underaged and unaccompanied boys who are caught up in refugee camps in Germany are the new target of radical Salafists (an ultraconservative movement within Sunni Islam). ${ }^{23}$ These traumatized, vulnerable children undergoing indoctrination are extremely susceptible to brain damage, as basic social, emotional, and cognitive neuronal networks are laid down in childhood.

\section{Masculinity and Violence}

Maleness is not only based on biology, but also on sociohistorical constructions of what it means to be male, which may be different in different cultures (and subcultures) and different times. However, in most societies, hegemonic masculinity ${ }^{24}$ has established patriarchal gender hierarchies. The traditional ideal of masculinity, stereotypically associated with action, dominance, achievement, power, competition, autonomy, pain tolerance, endurance, and independence, has been challenged currently, especially by younger generations. However, (adolescent) males may cope with an insecure identity, feelings of emasculization, inter- or intragender competition, grievances or experiences of social disintegration, and anxiety or hopelessness with exaggerated traditional masculinity norms. One of the most influential archetypes of masculinity is the fighter, respectively, the hero (others are the breadwinner or the rebel), eg, the superhero as presented in computer games and films, or the man-of-action hero, a specifically American ideal, which may manifest itself in symbolic everyday consumption, when opportunities to gain and demonstrate power and status have been reduced in our postindustrial times. $^{25}$

Aggression and violence are basic components of these masculinity ideals, and are legitimized as they aid in building and rebuilding social order (as is also supported by evolutionary explanations). For this reason, aggression and violence are at the same time principle means to demonstrate and reconstruct masculinity.

In the face of numerous rites of passage from boyhood to manhood in many preindustrial countries, theorists of various disciplines suppose that unlike womanhood, manhood is a precarious social status because it is relatively difficult to earn, but easy to lose. It is not a state of being, but rather a status that is conferred by others, particular other males. ${ }^{26}$ Becoming and remaining a "real man" entails suffering, proving, and fighting for social acceptance. Male identity seems particularly precarious in individuals with a high mental vulnerability due to experiencing stress in childhood, such as family violence, broken home, absence of the father, abuse, or other traumatization. Masculinity is a status that is earned and maintained primarily by actions and achievements, not so much by enduring personal attributes. ${ }^{27}$ Thus, risktaking physical behavior, including aggression and violence, is perceived as a way for males to demonstrate masculinity, particularly when it has been threatened.

Extremists, whether they are right-wing extremists or Islam extremists, share the perception that the world is perishing because their fundamentalist political/religious values are threatened by dominating Western ideologies of democracy, gender equality, and open society. Thus, it is not astonishing that these ideologies are linked to ultraconservative ideals of masculinity, as demonstrated in their propaganda, messages, and symbols. These ideals play an important part in young males' search for identity, leading them to believe that joining right-wing extremists would be a masculine rite of passage. ${ }^{28}$ Masculinity becomes a kind of hypermasculinity that includes a 
narrowly defined, exaggerated, and violence-oriented image of the warrior. ${ }^{28}$ Thus, young men have to prove their maleness in violent acts, with violence and combat as the only medium available where real masculinity can be acquired and verified.

This notion of hypermasculinity refers to the broader historical link between masculinity and the military, which has been constructed for the purpose of waging wars and is well documented, eg, by militarized masculinity in World Wars I and II. By equating military requirements with male values such as toughness, courage, honor, and willpower, violence becomes legitimized, normalized, and even glamorized, and thus is transferred into the self-concept. This instrumentalization of a unidimensional construct of masculinity, together with the Nazi ideology and visions of "Great Germany," might be one explanation for the ruthless violence conducted by German soldiers. Narratives of German soldiers who fought in World Wars I or $\mathrm{II}^{29}$ illustrate how intensely soldiers had internalized those expectations of hardness and ruthlessness to prove their masculinity and to avoid being emasculated for showing empathy for the enemy. The stronger their adaptation to martial masculinity, the better they were able to suppress their emotions, fears, scruples, and suffering. There is also evidence from secret recordings of conversations made by the British intelligence on German prisoners of war that some soldiers might have even enjoyed their killing and atrocities towards civilians; at the very least, some boasted about their actions. ${ }^{30}$ Militarized masculinity is one important cornerstone, not only for the war machinery, but also for the soldiers' experiences, their social roles, and their coping strategies. It might be seen as a complex defense mechanism in order to protect the self from traumatic experiences, and possibly as a (dysfunctional) way to cope with guilt.

Even today the soldier/warrior remains a key symbol of masculinity, ${ }^{31}$ and militarized masculinity remains central to the perpetuation of violence in international relations. $^{32}$

Coming back to Islamic terrorism, the fighter is simultaneously the sacred warrior who dies a martyr and is declared a hero both before and after his death. Monetary awards and support provided to the families of suicide bombers and other martyrs serves to reinforce the value and glamor of these extremely violent acts. ${ }^{33}$ Due to the fact that Islamic culture is a culture of honor, manhood and honor are closely related; they are even synonymous. ${ }^{34}$ Men are also viewed as owners and protectors of the women's honor in their families. They must protect their reputations and those of their families, even with violence when necessary, because dishonor means shame and emasculation. Thus, in cultures of honor, masculinity is even more precarious with perceived insults evoking aggression and violent behavior to restore manhood. In Islamic extremism, male honor can be only found in the role as warrior whereas female honor is found in the home.

Taken together, right-wing and Islamic extremism/ terrorism are based on common notions of archaic masculinity, which are perceived to be threatened and may result in terroristic actions to restore culture and manhood.

To give an individual example, an alternative view of the right-wing terrorist Anders Behring Breivik, who committed the 2011 Norway attacks and killed 77 young people, may demonstrate the driving forces of his bombing and shooting on the island Utoya: perceived Islamification, perceived breakdown of male dominance, and sexual liberation. ${ }^{35}$ Based on his analyses of the key documents of the case, Richards has supposed that Breivik's (unconscious) core fear was emasculation, an attack on his masculine identity arising from changes in society. "In this polemic, the fusion of feminism, feminization, matriarchy, androgyny and homosexuality threatens to engulf the Christian European heterosexual male, the hero of history who is now an object of contempt and hatred. It is here that Breivik's choice of Utoya as his target can be understood" (p. 45). ${ }^{35}$ Breivik's fantasies focused on re-establishing the medieval military order of the Knights Templar with grandiose ideas of omnipotence and restoration. According to Richards, "Breivik arrived at the island in a homemade police uniform to put an end to their sexual free-for-all, and to reassert the heroic figure of the patriarchal male who offers exemplary resistance to the tide of soft, corrupting pleasure that is washing over his civilization and dissolving its core categories" (p. 45). ${ }^{35}$

\section{Youth Bulges, Economic Stagnation, and Terrorism}

Some years ago, the cover of the German weekly magazine Der Spiegel declared in large type: "Young men: The world's most dangerous species." ${ }^{36}$ Of course this is an inadequate generalization. Although violent crimes and terroristic attacks are mostly committed by young males aged between 15 and 25, violence is a rather rare event on the individual level: in Germany, for example, about $2 \%$ of young men of this age are suspected to have committed one or more violent crimes. $^{37}$ But what about disproportional cohorts of adolescent males who live mainly in Islamic countries and become involved in terrorism? What makes young men susceptible to violence and terrorism from a macrolevel perspective? As the link between terrorism, types of terrorism, and social/societal conditions in different countries is extremely complex, it is not possible to identify common causes to explain terrorism as a general phenomenon. ${ }^{38}$ However, regarding the evolution of Islamic terrorism in developing countries, several main 
causes have been described: centuries of colonization, weakness of the state, political exclusion and social inequality, economic stagnation or decline, and negative effects of globalization. These factors are often cumulative and interacting, so that any mobilization for a peaceful change seems rather impossible. ${ }^{39}$ Thus, poverty and humiliation play important roles, but are not single causes of terrorism, as often has been argued. What has been also discussed is the question of whether the demographic explosion of so-called youth bulges, defined as large cohorts of young males aged 15-24 relative to the total adult population (over $20 \%$ ), are a breeding ground for violence and terrorism. ${ }^{40}$ Given a declining or stagnating economy in numerous Muslim societies (eg, Middle East, Africa, parts of Asia) with high rates of unemployment, many young men, mostly born after 1980, lacking the perspective that comes with age but with a lot of free time, feel humiliated and marginalized without any opportunities to prove themselves as honorable and masculine in culturally prescribed ways. ${ }^{41}$ Empirical evidence suggests an association between youth bulges and increased risk for political or terrorist violence, especially when economic opportunities are reduced and levels of education are low, but also in cases when highly educated young males do not find adequate jobs. It is not by chance that young engineers are overrepresented among Islamic terrorists in the Muslim countries, as Gambetta and Hertog ${ }^{42}$ found in their study on the correlation between extremism and education in Muslim countries. In their analysis of data regarding 497 members of extremist groups, they concluded that, aside from a specific mind-set typical for engineers the main reason for joining a terrorist group is experiencing frustrated expectations and relative deprivation: engineering is one of the most prestigious subjects, with high entry requirements in Muslim countries, thus young students expect corresponding high-status employment after graduation. However, because of economic development failures in North Africa and the Middle East, such high-status opportunities are extremely rare. These young engineers thus experience a large dissonance between merit and reward, which contributes to their radicalization. Interestingly, Gambetta and Hertog ${ }^{42}$ did not find an overrepresentation of engineers among terrorists in the West, in Singapore, or in Saudi Arabia, where graduates have far better professional opportunities. (In these areas Islamic terrorism has attracted more marginal males with lower education.)

To conclude, it is not that relatively large cohorts of young males are dangerous per se, but they may become dangerous under the conditions of low, respectfully, expanding education and concurrent economic stagnation, which restrain "doing" masculinity within cultural standards and gaining social acceptance. If such opportunities do not exist, political or religious violence, whether individual or collective, may serve as a powerful alternative for living without "male" achievements. Thus, most vulnerable to terrorist agitation are well-educated young men who are frustrated about the lack of opportunities in the developing countries in which they live. ${ }^{43}$

Another picture emerges, for example, in East Germany, where another bulge of young men comprises a new lower class in remote regions. Despite the reunification of West and East Germany in 1989, the eastern regions have remained less developed economically, with higher rates of unemployment, especially among young males. While many better education young women left for West Germany to improve their career options, young men, particularly from rural areas, remained in their home regions. For these young men, who are less educated and are unemployed, migrating to West Germany to find better jobs is not a realistic option. Also, due to the migration of young women, finding a mate and starting a family are difficult for young males, as in some regions the population of females aged 18-34 is down by $25 \% .{ }^{44}$ Economic restructuring, lack of education, and lack of adaptation have contributed not only to increasing violent criminality among males, but also to the rising attraction of far-right extremist groups that celebrate hyper-masculine, anti-feminist, anti-democratic, and racist ideologies. One of the reasons may be that young men perceive a profound devaluation of the traditional male gender role, including physical labor and breadwinning, because traditional male jobs in crafts, manufacturing, and construction (not requiring better education and being highly respected in the former German Democratic Republic) now have been severely affected by structural change of the economy and have lost importance. ${ }^{45}$ Given that many young men are poorly educated, have low income or are unemployed, and are without opportunity to start a family, they feel disadvantaged and emasculated, and may long for a revaluation of "genuine" masculinity.

Not surprisingly, the number of right-wing extremists in Germany has increased from 21,000 in 2014 to 22,600 in 2016, with half of them being regarded as violence oriented. ${ }^{46}$ Respectively, there has been a continuous and dramatic increase of right-wing extremist violence in the last few years. From 2014 to 2015, the number of violent offenses increased by $44 \%$, and refugee shelters were the predominant target (901 violent attacks out of 1005 total attacks).

\section{Group Dynamics and Identity Fusion}

There is a consensus among terrorist experts that psychological explanations of terrorism at the individual level are not sufficient. In order to best explain terrorist behavior, group psychology must be applied, with a 
particular focus on collective identity. This is all the more important because a unique psychopathological, psychological, or social profile for terrorists could not be derived from biographical analyses. ${ }^{2,47,48}$

Male alliances have always been the dominant unit in competitive public arenas, such as science, economy, sports, religion, secret societies, police, military, and politics-in particular political violence. Terrorists operate conventionally in groups/organizations; mentally unstable individuals are screened out, because they represent a security risk. ${ }^{2}$ Generally, $90 \%$ of all violent attacks by young males are performed in groups. This is because violence is a constitutive component in aggression-prone groups, which render putative status and power to the individual member. Furthermore, male groups are functional for males in general, as they are the key sites where masculinity is defined, proved, performed, and reconstructed. ${ }^{49}$

Searching for the roots of group violence, evolutionary theory suggests that living in groups is beneficial for the surviving of certain species (humans, primates, or rats), especially under conditions of limited resources (food, territory), which are embattled by rival male subgroups. Discriminating, attacking, casting out, or killing individuals belonging to the same species, but not to same group, seems to be a phylogenetic heritage, as has been manifested in countless wars and battles, as well as numerous genocides, throughout history. This phenomenon has been referred to by social psychology as intergroup conflict or minimal group paradigm. ${ }^{50}$ It is based on a profound evolutionary pattern of belonging to one group and separating from others with regard to differences such as ethnic, religious, linguistic, cultural, or national. As Tajfel ${ }^{51}$ has demonstrated in experimental studies, separation into groups can occur even on minimal, arbitrary, and meaningless differences that trigger intergroup discrimination; identity with a group is based solely on group membership, respectively, social categorization. On the individual level, being part of a group (eg, genetic, cultural, ideological) and identifying with the group's goals, values, and norms constitute a sense of social identity, pride, and self-esteem. Overvaluing the own group ("we") and devaluating the outgroup ("they") results in an increased self-image of the group members and subsequently an increased group cohesiveness. Social identity theory states that the more strongly a member identifies with the group, the stronger his social identity will be, but the more his personal identity will fade. He will become a puppet. However, this idea generates new questions. Are puppets able to sacrifice themselves for their group? Were the soldiers of the Nazi regime puppets without personal identity? It is possible that extreme pro-group behavior, like suicide bombing or mass murder, may not be fully explained by this approach.
Based on social identity theory, a more sophisticated explanation has been developed by Swann et al. ${ }^{52,53}$ who put forward the concept of "identity fusion." Identity fusion occurs in different degrees due to a visceral feeling of oneness with the group, while personal identity is retained and channeled into pro-group action. In addition to the synergetic connection of personal and collective identity, the perception of the group as a family is crucial for motivation. Highly fused group members cultivate close ties to other group members, as well as to the group as a whole. Thus, it is not surprising that actors whose personal identity is highly fused within a unique collective identity would kill and die for the sake of their collective when it is threatened, because they perceive the bonds as family-like. In-depth case and field studies of terrorist groups by the anthropologist Scott Atran ${ }^{54,55}$ suggest that "people almost never kill and die (just) for the cause, but for each other: for their group, whose cause makes their imagined family of genetic strangers - their brotherhood, fatherland, motherland, homeland" (p. 33). ${ }^{54}$

Due to the dangers and costs of participation in terrorism, terrorist groups are more tight-knit than other voluntary associations. Obviously, this may be one of the most attractive factors for potential terrorists. There is evidence from interviews with terrorists that many join violent groups seeking challenges and excitement, but above all they seek friendship and fellowship. These motives seem more important to them than the political purpose or ideology of their collective. ${ }^{5}$

Such non-ideological motivations are also supported for right-wing extremists. ${ }^{56-58}$ From a perspective of social disintegration, ${ }^{59}$ right-wing violence among young males can best be explained as a consequence of deficits in fundamental recognition needs. It is a sort of projective coping of individual deficits perceived as being caused by others. Ideology often serves as a justification of violent acts.

\section{Lone-Wolf Terrorists Are Different}

Lone-wolf terrorists prepare and commit violent acts alone, without command structure or material assistance from terrorist groups/organizations. Nevertheless, they may be influenced or motivated by terrorist groups, and may act in support of these groups. Although lone-wolf terrorism is rare, it has been a historical, and now increasing, phenomenon in the US and Europe, being inspired not only by ISIL but also by far-right extremism. It is argued that the surge of lone-wolf terrorism is due to pressure from security services forcing a tactical adaptation, and terrorist groups, particularly ISIL, who call on those who share their ideology to act alone without direction or support. ${ }^{60}$ The Internet has made it easier than ever before to distribute and find radicalizing material and instructions on how to conduct attacks. ${ }^{61}$ 
The profile of lone actors has proven to be rather heterogeneous, while the only common factor is being male. ${ }^{62}$ Political or religious ideology seems not to be the only motivation for their attacks, but personal grievances also contribute. Current research on lone actor terrorists indicates that they differ significantly from members of terrorist groups; they seem to have much more in common with apolitical mass murderers or school shooters, ${ }^{63}$ as they tend to combine their personal grievances and frustrations with religious or political ideologies. ${ }^{64}$ This is a commonality that distinguishes lone actors from organized terrorists who share collective grievances. However, because of the complex constellation of contributing factors in each case, it is not possible to identify a unique psychological profile of the typical lone-wolf terrorist. Decades of research have attempted to find such unique explanations, ${ }^{65}$ starting with psychopathological approaches in the 1970s (mostly speculations based on anecdotal observations) followed by psychoanalytic approaches during the 1980s, with particular emphasis on narcissism. In the 1990s and 2000s, these approaches have been dismissed due to methodological and empirical reasons, while group dynamics, based on improved data collection and primary interviews with terrorists, became the new dominating concept to understand terrorist motivation in general. However, in the face of increasing lone-wolf terrorism, group dynamics cannot be a sufficient explanation, even though lone attackers may have self-radicalized via Internet propaganda of terrorist groups and may perceive themselves as members of a virtual community. Consequently, previously dismissed mental health and personality factors must be revisited on the basis of the existing empirical evidence, while extreme positions must be questioned ("they are all mentally ill" or "a terrorist cannot be mentally ill"65). For example, with respect to mental illness, it has often been argued that mental illness is the primary reason for violent behavior, and that a mentally ill person is not able to rationally plan violent attacks. However, it has been shown that lone-actor terrorists diagnosed with mental illness frequently display rational motivations ${ }^{65}$ and are capable of sophisticated attack planning. ${ }^{66}$ In fact, mental health problems are significantly more common in loneactor terrorists compared to group-based terrorists. ${ }^{67,68}$ Corner and Gill ${ }^{67}$ also support the role of social isolation in lone actors, as they found that $53 \%$ of lone actors were socially isolated; however, this isolation was due to a recent interpersonal conflict rather than a chronic state. Other authors emphasize that, while lone wolves physically isolate themselves from society, they simultaneously seek recognition for their causes through spoken statements and threats, manifestos, e-mail messages, texting, and videotaped proclamations. ${ }^{64}$

As quantitative and qualitative analyses of lone-actor terrorists indicate, unsolved psychosocial problems may play an important role in self-radicalizing and conducting terroristic attacks, as is also true for school shooters. Both lone actors and school shooters perceive themselves as outsiders and are unable to accept defeat or to cope with cumulative disappointment, and so they end up in a state of chronic frustration and aggression. ${ }^{69,70}$

Some sociologists have claimed that searching for reasons and contributing factors to explain violence and terror would legitimize and victimize the perpetrators while ignoring their main motivation: experiencing total power over their victims, feeling omnipotent, and being a hero and avenger. However, this is no contradiction. Whether lone-actor terrorist, school shooter, or grouprelated terrorist, they belong to the "laughing killer" type. ${ }^{71}$ According to Theweleit, "they are men who enjoy their murderous game, who see themselves as part of a higher power that condones all of this. They laugh as they celebrate the sanctioned crime, their unpunished, godlike actions." ${ }^{72}$ Anders Breivik, the Norwegian mass murderer, burst into ecstatic laughter during his killing spree, and was relaxed and smiling during the trial. So did others: the killer of Orlando, when he shooted in the head of his wounded victims next to him, the killer of Dallas, of Charleston, North Carolina, or the killers of Bataclan, Paris, who apparently enjoyed their atrocity.

With respect to sociodemographic characteristics of lone shooters, the existing literature indicates no consistent evidence of economic disadvantage or poorer education compared to the general population, but points to a higher rate of unemployment. ${ }^{62}$ Obviously, there seem to be differences depending on the different ideologies. Compared to Islamist lone actor terrorists, right-wing lone actors have a lower education, and are often unemployed, single, and have never been married.

In sum, sociodemographic data at best demonstrate the variability of terrorists' backgrounds. In the words of Adam Deen, an ex-Jihadi and now counter-terrorist outreach worker in London: "The predominant factor in radicalisation is the ideology [of Islam]—it is the ideas that move people. I didn't come from a poverty-stricken background or broken home. I went to university, I didn't feel angry and I was apolitical. Yet, I was indoctrinated with a radical Islamist ideology and became impassioned with the idea of an Islamic state."73

\section{Conclusions}

In the face of the multiple factors likely associated with terrorism, it is obvious that there exists no unique "master explanation." Research can only offer approaches to understanding terrorism from a variety of perspectives, thus producing even more complexity.

Nevertheless, clear answers are needed for many reasons, not the least of which is practical approaches to counterterrorism. Thus, in political and public debates, 
different explanations regarding root causes (necessary and sufficient causes) have been favored. One popular "master explanation" has been humiliation, as Islamic terrorists themselves, and also terrorism experts, have claimed humiliation to be a motivating force. According to the historian Goldhagen, ${ }^{74}$ there are, however, many historical examples in non-Middle Eastern countries where humiliation did not result in devastating terror. This means that there is no deterministic link between humiliation and terror on the macro-social level, just as there is no deterministic link between frustration and aggression/ violence on the micro-social level, as was supposed by early aggression theory. Of course, real or perceived humiliation and frustration are playing important roles, but what significantly triggers violence in this context is the connection with fundamentalist political-religious ideas of a better world that shape political goals and result in destructive power politics and terror. This is a continuous pattern throughout history and may reflect an anthropological matter of fact. Numerous historical examples show how men and unidimensional notions of masculinity have been instrumentalized for political violence by propagating individual significance as a hero, avenger, or warrior in the name of God or for any goal greater than oneself. From a gender perspective, humiliation can also be understood as a sense of being emasculated-by the West, women, their fathers, culture, migrants, globalization, or peers. As has been shown, masculinity is a precarious status that must be continuously performed, reassured, and proved. Joining collective terrorism, as well as acting alone, offers perceived opportunities to re-establish and validate masculinity, however in exaggerated forms of destructive hypermasculinity.

To conclude, in addition to ideological, political, economic, regional, demographic, or psychological causes contributing to terrorism, experiences of threatened masculinity may be an underlying factor and driving force that contribute to better understanding of collective and lone actor terrorism.

\section{Disclosures}

Anne Maria Möller-Leimkühler does not have anything to disclose.

\section{REFERENCES:}

1. Schmidt AP. The revised academic consensus definition of terrorism. Perspectives on Terrorism. 2012; 6(2): 158-159.

2. Post JM. Terrorism and right-wing extremism: the changing face of terrorism and political violence in the 21 st century: the virtual community of hatred. Int J Group Psychother. 2015; 65(2): 243-271.

3. Institute for Economics \& Peace. Global terrorism index 2016. http:// economicsandpeace.org/wp-content/uploads/2016/11/GlobalTerrorism-Index-2016.2.pdf?bcsi_scan_64377d2312a 1e457=0\&bcsi_scan_filename=Global-Terrorism-Index-2016.2.pdf.
4. White JR. Terrorism and Homeland Security, 7th ed. Belmont, CA: Wadsworth, Cengage Learning; 2012.

5. Bergen P, Cruickshank P. The Iraq effect: war has increased terrorism sevenfold worldwide. Mother Jones. 2007: 1-7. http:// www.motherjones.com/politics/2007/03/iraq-effect-war-iraq-andits-impact-war-terrorism-pg-2.

6. Pew Research Center. Unfavorable views of Jews and Muslims on the increase in Europe. http://www.pewglobal.org/2008/09/17/ unfavorable-views-of-jews-and-muslims-on-the-increase-in-europe/. September 17, 2008.

7. Bremmer I. These 5 facts explain why Europe is ground zero for terrorism. Time. http://time.com/4268579/brussels-attacksislamist-terrorism-isis/. March 22, 2016.

8. Renard T. Fear not: a critical perspective on the terrorist threat in Europe. Security Policy Brief No. 77; 2016. Egmont Royal Institute for International Relations, Brussels.

9. Niehoff D. Not hardwired: the complex neurobiology of sex differences in violence. Violence and Gender. 2014; 1(1): 19-24.

10. Staniloiu A, Markowitsch H. Gender differences in violence and aggression-a neurobiological perspective. Procedia - Social and Behavioral Sciences. 2012; 33: 1032-1036.

11. Caspi A, McClay J, Miffitt TE, et al. Role of genotype in the cycle of violence in maltreated children. Science. 2002; 297(5582): 851-854.

12. Bogerts B, Möller-Leimkühler AM. Neurobiologische Ursachen und psychosoziale Bedingungen individueller Gewalt. Nervenarzt. 2013; 84(11): 1329-1344.

13. Montoya ER, Terburg D, Bos PA, van Honk J. Testosterone, cortisol, and serotonin as key regulators of social aggression: a review and theoretical perspective. Motiv Emot. 2012; 36(1): 65-73.

14. Walderhaug E, Magnusson A, Neumeister A, et al. Interactive effects of sex and 5-HTTLPR on mood and impulsivity during tryptophan depletion in healthy people. Biol Psychiatry. 2007; 62(6): 593-599.

15. Lighthall NR, Mather M, Gorlick MA. Acute stress increases sex differences in risk seeking in the balloon analogue risk task. PLoS One. $2009 ;$ 4(7): e6002.

16. Taylor SE, Klein LC, Lewis BP, Gruenewald TL, Gurung RA, Updegraff JA. Biobehavioral responses to stress in females: tend-and-befriend, not fight-or-flight. Psychol Rev. 107(3): 411-429.

17. Stanton SJ, Wirth MM, Waugh CE, Schultheiss OC. Endogenous testosterone levels are associated with amygdala and ventromedial prefrontal cortex responses to anger faces in men but not women. Biol Psychiatry. 2009; 81(2): 118-122.

18. Steinberg L. A social neuroscience perspective on adolescent risk-taking. Dev Rev. 2008; 28(1): 78-106.

19. Eaton DK, Kann L, Kinchen S, et al. Youth risk behaviour surveillance - United States, 2011. MMWR Surveill Summ. 2012; 61(4): 1-162.

20. Telzer EH. Dopaminergic reward sensitivity can promote adolescent health: a new perspective on the mechanism of ventral striatum activation. Dev Cogn Neurosci. 2016; 17: 57-67.

21. Goudie C, Markoff B. How ISIS recruiting videos mirror Hollywood scripts. http://abc7chicago.com/news/how-isis-recruiting-videosmirror-hollywood-scripts/1194173/. February 9, 2016.

22. Riegler T. Through the lenses of Hollywood: depictions of terrorism in American movies. Perspectives on Terrorism. 2010; 4(2): 35-45.

23. Hall A. ISIS has launched a new recruitment drive among unaccompanied youngsters in Germany's refugee camps. http://www. dailymail.co.uk/news/article-3799915/ISIS-launched-new-recruitmentdrive-unaccompanied-youngsters-Germany-s-refugee-camps-officialswarn-group-plots-Paris-style-carnage. September 21, 2016. 
24. Connell RW, Messerschmidt JW. Hegemonic masculinity: rethinking the concept. Gender and Society. 2005; 19(6): 829-859.

25. Holt DB, Thompson CJ. Man-of-action heroes: the pursuit of heroic masculinity in everyday consumption. Journal of Consumer Research. 2004; 31(2): 425-440.

26. Ferber AL, Kimmel MS. The gendered face of terrorism. Sociology Compass. 2008; 2(3): 870-887.

27. Bosson JK, Vandello JA. Precarious manhood and its links to action and aggression. Current Directions in Psychological Science. 2011; 20(2): 82-86.

28. The Swedish Agency for Youth and Civil Society. Young and extreme -a youth and gender perspective on violent extremism. https:// www.mucf.se/sites/default/files/publikationer_uploads/youngand-extreme.pdf. 2016.

29. Werner F. Soldatische Männlichkeit im Vernichtungskrieg. Geschlechtsspezifische Dimensionen der Gewalt in Feldpostbriefen 1941-1944. In Didczuneit V, Ebert J, Jander T, eds. Schreiben im Krieg - Schreiben vom Krieg. Feldpost im Zeitalter der Weltkriege. Essen, Germany: Klartext; 2011: 283-294.

30. Neizel S, Welzer H. Soldaten: On Fighting, Killing and Dying: The Secret Second World War Tapes of German POWs. New York: Simon \& Schuster/Paula Wiseman Books; 2012.

31. Morgan DHJ. Theater of war: combat, the military, and masculinities. In: Brod H, Kaufman M, eds. Theorizing Masculinities. London: Sage; 1994: 165.

32. Eichler M. Militarized masculinities in international relations. Brown Journal of World Affairs. 2014; 21(1): 81-93.

33. McCue $\mathrm{C}$, Haahr K. The impact of youth bulges on Islamist radicalization and violence. https://www.ctc.usma.edu/posts/ the-impact-of-global-youth-bulges-on-islamist-radicalization-andviolence. 2008.

34. Cohen D, Nusbett RE, Bowdle BF, Schwarz N. Insult, aggression, and the southern culture of honor: an "experimental ethnography. J Pers Soc Psychol. 1996; 70(5): 945-959.

35. Richards B. What drove Anders Breivik. Contexts. 2014; 13(4): 42-47.

36. Junge Männer. Die gefährlichste Spezies der Welt. http://www. spiegel.de/spiegel/print/d-55294591.html. Der Spiegel. 2008;2.

37. Loeber R, Hoeve M, Slot NW, van der Laan PH. Persisters and desister in crime from adolescence into adulthood. London: Routledge; 2012.

38. Newman E. Exploring the "root causes" of terrorism. Studies in Conflict \& Terrorism. 2006; 29(8): 749-772.

39. Kivimäki T, Montesanti E. Global terrorism: causes, consequences and solutions. Global Research. http://www.globalresearch.ca/globalterrorism-causes-consequences-and-solutions/5529247. 2016.

40. Urdal H. A clash of generations? Youth bulges and political violence. International Studies Quarterly. 2006; 50(3): 607-629.

41. Aslam M. Gender-Based Explosions: The Nexus Between Muslim Masculinities, Jihadist Islamism and Terrorism. Tokyo: United Nations University Press; 2012.

42. Gambetta D, Hertog S. Engineers of Jihad: The Curious Connection Between Violent Extremism and Education. Princeton, NJ: Princeton University Press; 2016.

43. Kivimäki T. Executive summary. In Kivimäki T, ed. Development Cooperation as an Instrument in the Prevention of Terrorism. Copenhagen: The Royal Danish Ministry of Foreign Affairs/Nordic Institute of Asia Studies; 2003.

44. Kroehnert S, Klingholz R. Not am Mann. Von Helden der Arbeit zur neuen Unterschicht? Berlin Institut für Bevölkerung und Entwicklung. http://www.berlin-institut.org/fileadmin/ user_upload/Studien/Not_am_Mann_Webversion.pdf. 2007.

45. Kroehnert S, Vollmer S. Where have all young women gone? Gender-specific migration from East to West Germany. World Development Report. Background Paper. http://siteresources. worldbank.org/INTWDR2009/Resources/42310061204741572978/Vollmer.pdf. 2008.
46. Koehler D. Right-wing extremism and terrorism in Europe. PRISM. 2016; 6(2): 85-104.

47. Sageman M. Understanding terror networks. Foreign Policy Research Institute. httpp://www.fpri.org/enotes/20041101. middleeast.sageman.understandingterrornetwarks.html. 2004.

48. McGilloway A, Ghosh P, Bhui K. A systematic review of pathways to and processes associated with radicalization and extremism amongst Muslims in Western societies. Int Rev Psychiatry. 2015; 27(1):39-50.

49. Möller-Leimkühler AM, Bogerts B. Kollektive Gewalt. Neurobiologische, psychosoziale und gesellschaftliche Bedingungen. Nervenarzt. 2013; 84(11): 1345-1358.

50. Tajfel H, Turner J. An integrative theory of intergroup conflict. In Hogg MA, Abrams D, eds. Intergroup Relations. New York: Psychology Press; 2001: 94-109.

51. Tajfel H. Experiments in intergroup discrimination. Scientific American. 1970; 223: 96-102.

52. Swann WB, Jetten J, Gómez A, Whitehouse H. When group membership gets personal: a theory of identity fusion. Psychol. Rev. 2012; 119(3): 441-456.

53. Swann WB, Buhrmester MD. Identity fusion. Current Directions in Psychological Science. 2015; 24(1): 52-57.

54. Atran S, Henrich J. The evolution of religion: how cognitive byproducts, adaptive learning heuristics, ritual displays, and group competition generate deep commitments to prosocial religions. Biological Theory. 2010; 5(1): 18-30.

55. Atran S. The devoted actor: unconditional commitment and intractable conflict across cultures. Current Anthropology. 2016; 57(13): S192-S203.

56. Abrahms M. What terrorists really want. International Security. 2008; 32(4): 78-105.

57. Marneros A. Hitlers Urenkel. Rechtsradikale Gewalttäter. Bern, Switzerland: Scherz; 2002.

58. Simi P, Windisch S, Sporer K. Recruitment and Radicalization Among US Far Right Terrorists. College Park, MD: START; 2016.

59. Sitzer P, Heitmeyer W. Right-wing extremist violence among adolescents in Germany. New Dir Youth Dev. 2008; 2008(119): 169-185.

60. Pantucci R, Ellis C, Chaplais L. Lone-Actor Terrorism: Literature Review. The Royal United Services Institute for Defense and Security Studies. London, UK: Stephen Austin and Sons; 2015.

61. Weimann G. Lone wolves in cyberspace. Journal of Terrorism Research. 2012; 3(2): 75-90.

62. Gill P, Horgan J, Deckert P. Bombing alone: tracing the motivations and antecedent behaviors of lone-actor terrorists. J Forensic Sci. 2014; 59(2): 425-435.

63. McCauley C, Moskalenko S, Van Son B. Characteristics of lone-wolf violent offenders: a comparison of assassins and school attackers. Perspectives on Terrorism. 2013; 7(1): 4-24.

64. Hamm M, Spaaj R. Lone wolf terrorism in America: using knowledge of radicalization pathways to forge prevention strategies. Final Report. https://www.ncjrs.gov/pdffiles1/nij/grants/248691. 2015.

65. Gill P. Lone-Actor Terrorists: A Behavioural Analysis. London: Routledge; 2015.

66. Borum R. Informing lone-offender investigations. Criminology \& Public Policy. 2013; 12(1): 103-112.

67. Corner E, Gill P. A false dichotomy? Mental illness and lone-actor terrorism. Law Hum Behav. 2015; 39(1): 23-34.

68. Gruenewald J, Chermak S, Freilich JD. Distinguishing "loner" attacks from other domestic extremist violence. Criminology \& Public Policy. 2013; 12(1): 65-91.

69. Langman P. Amok im Kopf. Warum Schüler töten. Weinheim, Germany: Beltz; 2009.

70. Böckler N, Hoffmann J, Zick A. The Frankfurt Airport attack: a case study on the radicalization of a lone-actor terrorist. Journal of Threat Assessment and Management. 2015; 2(3-4): 153-163. 
71. Theweleit K. Das Lachen der Täter. Breivik u.a. St. Pölten Salzburg-Wien: Residenz Verlag; 2. Auflage; 2015.

72. Can Europe's populists be blamed for Anders Breivik's crusade? http://www.spiegel.de/international/europe/the-trail-of-evil-caneurope-s-populists-be-blamed-for-anders-breivik-s-crusade-a777710.html. August 1, 2011.
73. Forsythe P. Profiling ideology the best way to combat terrorism. http://thebattleoftours.blogspot.de/2016/04/profiling-ideologybest-way-to-combat.html. April 11, 2016.

74. Goldhagen DJ. The humiliation myth. Democracy Journal. http://democracyjournal.org/magazine/4/the-humiliation-myth/. 2007. 